\title{
Two and Three-Electrode Impedance Studies on 18650 Li-ion Cells
}

\author{
G. Nagasubramanian \\ 2521 Lithium Battery R\&D \\ Sandia National Laboratories \\ Albuquerque, NM 87185
}

\begin{abstract}
Two and three electrode impedance measurements were made on $18650 \mathrm{Li}$-ion cells at different temperatures ranging from $35^{\circ} \mathrm{C}$ to $-40^{\circ} \mathrm{C}$. The ohmic resistance of the cell is nearly constat the temperature range studied although the total cell impedance increases by an order of magnitude in the same temperature range. In contrast to what is commonly believed, we show from our three-electrode impedance results that, the increase in cell impedance comes mostly from the cathode and not from the anode. Further, the anode and cathode contribute to both the impedance loops (in the NyQuist plot).
\end{abstract}

In recent years $\mathrm{Li}$-ion batteries are being used in a variety of electronic products including camcorders, lap top computers, cellular telephones and also are being considered for military and space applications. The explosive growth in the use of this chemistry in turn has generated interest in the evaluation of the Li-ion cells using techniques such as impedance ${ }^{1}$, Accelerated Rate Calorimeter ${ }^{2}, 3$ (ARC), aimed at understanding the fundamental electrical, electrochemical, thermal behavior, capacity degradation etc.. Few papers are published on the full cell impedance behavior of the 18650 cells. A typical NyQuist plot of the cell impedance shows an inductive tail at high frequency followed by two loops at lower frequencies. The inductive tail has been observed by others for $\mathrm{Li}-\mathrm{MoS}_{2}$ cells ${ }^{4}$ and in that case has been attributed to the jelly-roll and/or porous electrode design. The inductive tail in the case of 18650 cells could also be due to a similar design feature. None of the publications except one ${ }^{5}$ has assigned which loop corresponds to which electrode. Ozawa $^{5}$, from his 2-electrode impedance data, has assigned the larger loop at low frequencies in the NyQuist plot to the anode and the smaller (left to the larger loop) loop to the cathode. He has supported these assignments with the observations from two related impedance measurements. The first measurement was carried out on a fully charged carbon anode (similar to the one used in his two- electrode measurement) in a half-cell and the other measurement was carried out on a $\mathrm{LiCoO}_{2}$ cathode electrode of different areas, again in half-cells. The halfcell measurement with carbon anode shows one large semicircle similar to the large one in his full cell measurement and $\mathrm{LiCoO}_{2}$ half-cell studies gave small loop which increased in size as the area of the cathode was decreased. Two other publications, 6 subsequently published, used these assignments to interpret their impedance data.

At Sandia National Laboratories currently we are evaluating commercial 18650 and larger Li-ion cells to define their electrical, electrochemical and thermal performance envelopes for different applications. The charge/discharge performance of these cells at subambient temperatures is very poor ${ }^{8}$. We have studied systematically the 2 and 3-electrode impedance characteristics of the commercial $18650 \mathrm{Li}$-ion cells. This letter describes some of our impedance studies. Our threeelectrode impedance data clearly indicates that, the assignments by others of the loops, in the NyQuist plot, from the two- electrode measurements to the cathode and anode are erroneous. 


\section{Experimental}

Although we have studied the impedance characteristics of 18650 cells of different manufacturers we will discuss only data pertaining to the Sony. cells since the behavior of the other cells is similar to that of the Sony cell. For cell impedance measurement, a Princeton Applied Research (PAR) potentiostat (model 273A) equipped with a 1255 Solatron Oscillator and controlled by impedance software Model 398 was used. The impedance of the Li-ion cells was measured from $65 \mathrm{kHz}$ to $0.1 \mathrm{~Hz}$ as a function of temperature for three different OCVs (Open Circuit Voltages). The cell impedance was measured both in a 2-electrode and 3-electrode configuration. We performed the 3-electrode (the third electrode being a $\mathrm{Li}$ reference electrode) impedance measurements to locate more accurately the source of the impedance increase especially at lower temperatures and to correctly assign the two loops in the NyQuist plots to the two electrodes (anode and cathode). The cell configuration was modified to accommodate the $\mathrm{Li}$ reference electrode in the mandrel hole that runs along the length of the cell at the center. Both the bottom and the top of the cell were carefully cut-open in a glove box with a Dremel tool and subsequently tabs were attached to the anode and cathode for electrical contacts. After the cell was opened at both ends, it was never exposed to air, to prevent degradation of the cell components by reacting with oxygen and water vapor. A Li reference electrode made before hand was introduced in to the cell through the mandrel hole. The reference electrode assembly consists of a thin platinum wire and $\mathrm{a} \sim 1 \mathrm{~mm}$ diameter glass tube. The platinum wire is fused at one end to the glass tubing. The other end of the platinum wire sticks out the opposite end of the glass tubing for electrical contact.
The fused end of the glass tubing was made flat by polishing to form a platinum disc electrode of tiny area and lithium metal was cold-welded to the flat platinum electrode. This completes the reference electrode assembly. The cell with the reference electrode was kept in a plastic beaker to which Sony type electrolyte \{Ethylene Carbonate, Propylene Carbonate and Diethyl Carbonate $(1: 1: 2 \mathrm{v} / \mathrm{v})$ containing $1 \mathrm{M}$ $\left.\mathrm{LiPF}_{6}\right\}$ was added for impedance studies. This assembly was then put in a "Kerr Jar" for easy handling. The initial operational checks (for internal shorts, open circuit voltage etc.) were done in a glove box. The impedance measurements were carried out at different temperatures and cell temperatures during measurements were controlled with a Tenney Jr. temperature chamber (benchtop model, Union, New Jersey).

\section{Results and Discussion}

\section{Impedance Studies}

2-Electrode Measurements:

Before opening the cells for the 3electrode studies 2-electrode impedance measurements were made at different temperatures and at three OCVs. In Figure 1 is shown a typical NyQuist plot for the Sony cell at $25^{\circ} \mathrm{C}$ at $4.1 \mathrm{~V}$. As described above the plot exhibits an inductive tail followed by a small loop and a larger loop. The high frequency intercept at the $\mathrm{x}$-axis corresponds to the ohmic cell resistance. In Figure 2 are shown similar NyQuist plots at different temperatures from $35^{\circ} \mathrm{C}$ to $-40^{\circ} \mathrm{C}$. These plots indicate that the ohmic resistance of the cell remains almost constant while the total cell impedance (low frequency $x$-axis intercept) increases by nearly 2 orders of magnitude. Similar results have been reported by Andermanet al. ${ }^{8}$ 


\section{DISCLAIMER}

This report was prepared as an account of work sponsored by an agency of the United States Government. Neither the United States Government nor any agency thereof, nor any of their employees, make any warranty, express or implied, or assumes any legal liability or responsibility for the accuracy, completeness, or usefulness of any information, apparatus, product, or process disclosed, or represents that its use would not infringe privately owned rights. Reference herein to any specific commercial product, process, or service by trade name, trademark, manufacturer, or otherwise does not necessarily constitute or imply its endorsement, recommendation, or favoring by the United States Government or any agency thereof. The views and opinions of authors expressed herein do not necessarily state or reflect those of the United States Government or any agency thereof. 


\section{DISCLAIMER}

Portions of this document may be illegible in electronic image products. Images are produced from the best available original document. 
In Figure 3 is shown NyQuist plots for three OCVs $(4.1, \mathrm{~V}, 3.6, \mathrm{~V}$ and 3.1, V) at $-40^{\circ} \mathrm{C}$. Again the ohmic resistance is the same for the three OCVs although the cell impedance increases going from 4.1 $V$ to $3.1 \mathrm{~V}$. In Figure 4 is shown the plot of ohmic resistance (high frequency $\mathrm{x}$-axis intercept in a NyQuist plot) as a function of temperature at two OCVs. The ohmic resistances were comparable at the two OCVs except at $-40^{\circ} \mathrm{C}$ where the ohmic resistance at $4.1 \mathrm{~V}$ is lower than at $3.1 \mathrm{~V}$. At $3.6 \mathrm{~V}$ the ohmic resistance was comparable to the values at 4.1 and $3.1 \mathrm{~V}$.

3-Electrode Measurements:

Although the 2-electrode measurement indicates that the interfacial impedance. dominates, especially at lower temperatures the cell impedance it doesn't tell us whether it is the anode or the cathode electrode/electrolyte impedance is responsible for the increase. To identify which electrode is the cause for the impedance increase we carried out 3-electrode impedance studies. The cell fabrication for the measurement is described above in the experimental section. In Figures 5 and 6 are given NyQuist plots for the anode, cathode and the full cell impedance of the opened cell (measured in 2-electrode mode) at $0^{\circ} \mathrm{C}$ and $-20^{\circ} \mathrm{C}$ respectively. The plots clearly show that the impedance of the anode/electrolyte interface is lower than the cathode/electrolyte interface which dominates the overall cell impedance. Further, both electrodes contribute to both the loops with the cathode contributing the most to the second loop. In Figure 7 are compared the sum of the anode and cathode impedances and the 2-electrode impedance (from figure 5) at $0^{\circ} \mathrm{C}$. In Figure 8 are shown similar plots at $-20^{\circ} \mathrm{C}$. The impedances obtained from the 2-electrode measurement and the sum of the anode and cathode (obtained from the 3-electrode measurements) are comparable which provides internal check for the correctness of the measurement. Our 3-electrode impedance data very clearly indicates that:

1) both the anode and the cathode contribute to the two loops and

2) the cell impedance comes mostly from the cathode/electrolyte interface and not from the anode/electrolyte interface as suggested earlier by others.

\section{Conclusions}

2- and 3-electrode impedance studies were made on $18650 \mathrm{Li}$-ion cells at different temperatures ranging from $35^{\circ} \mathrm{C}$ to $-40^{\circ} \mathrm{C}$. Although the ohmic resistance remains almost constant, the total cell resistance increases by 100 times at sub-ambient temperatures. The increase in cell impedance comes mostly from the cathode/electrolyte interface as shown by our 3-electrode study.

\section{Acknowledgments}

Sandia National Laboratories is a multiprogram laboratory operated by Sandia Corporation, a Lockheed Martin Company, for the United States Department of Energy under contract DE-AC04-94AL85000. I am grateful to D. R. Bradley for performing the electrochemical measurements.

\section{References}

1. (a) G. Nagasubramanian and Rudy Jungst, J. Power Sources 72, 189 (1998) (b) G. Nagasubramanian, R. Jungst, and D. Doughty, J. Power Sources (accepted for publication). 
2. J.Shi, C. Lampe-Onnerud, P. Ralbovsky, P. Onnerud, E. Carlson, and B. Barnett, in Lithium Batteries, PV 9816, p. 493, The Electrochemical Society Proceedings Series, Pennington, NJ (1999).

3. J-S Hong, H. Maleki, S. Al Hallaj, L. Redey, and J. R. Selman, J. Electrochem. Soc., 145, 1489(1998).

4. F. C. Laman, M. W. Matsen, and J. A. R. Stiles, J. Electrochemical Soc., 133, 2441(1986).

5. K. Ozawa, Solid State Ionics, 69, 212(1994)

6. P. O. Braatz, K. C. Lim, A. M. Luckner, W. H. Smith Jr., J. D. Margenum, and H. S. Lim, ECS Extended Abstracts Vol. 97-2, Abstract \# 121, 1997.

7. M. J. Isaacson, M. E. Daman, and R. P. Hollandsworth, Proceedings of the $32^{\text {nd }}$ Intersociety Energy Conversion Energy Conference, 1, 31(1997).

8. G. Nagasubramanian, Solid State Ionics (submitted).

9. J. Fan, G. Nagarajan, R. M. Spotnitz, and $\mathrm{M}$. Anderman in Lithium Batteries, PV 98-16, p. 512, The Electrochemical Society Proceedings Series, Pennington, NJ (1999). 


\section{Figure Captions}

Figure 1. NyQuist Plot of a Fully Charged Sony $18650 \mathrm{Li}$-ion cell at $25^{\circ} \mathrm{C}$.

Figure 2a. NyQuist Plot of a Sony $18650 \mathrm{Li}-$ ion cell at Different Temperatures from $35^{\circ} \mathrm{C}$ to $0^{\circ} \mathrm{C}$.

Figure 2b. NyQuist Plot of a Sony $18650 \mathrm{Li}-$ ion cell at $-20^{\circ} \mathrm{C}$ and $-40^{\circ} \mathrm{C}$.

Figure 3. NyQuist Plot of a Sony $18650 \mathrm{Li}-$ ion cell at $-40^{\circ} \mathrm{C}$ for Three Open Circuit Voltages.

Figure 4. Plot of ohmic resistance vs. Temperature for Sony Cell at two Open Circuit Voltages.

Figure 5. NyQuist Plots of impedances of the anode, cathode and the full cell at $0^{\circ} \mathrm{C}$.

Figure 6. NyQuist Plots of impedances of the anode, cathode and the full cell at $-20^{\circ} \mathrm{C}$.

Figure 7. NyQuist Plots of impedances of the full cell and the sum of the anode and cathode and at $0^{\circ} \mathrm{C}$.

Figure 8. NyQuist Plots of impedances of the full cell and the sum of the anode and cathode and at $-20^{\circ} \mathrm{C}$. 
Figure 1

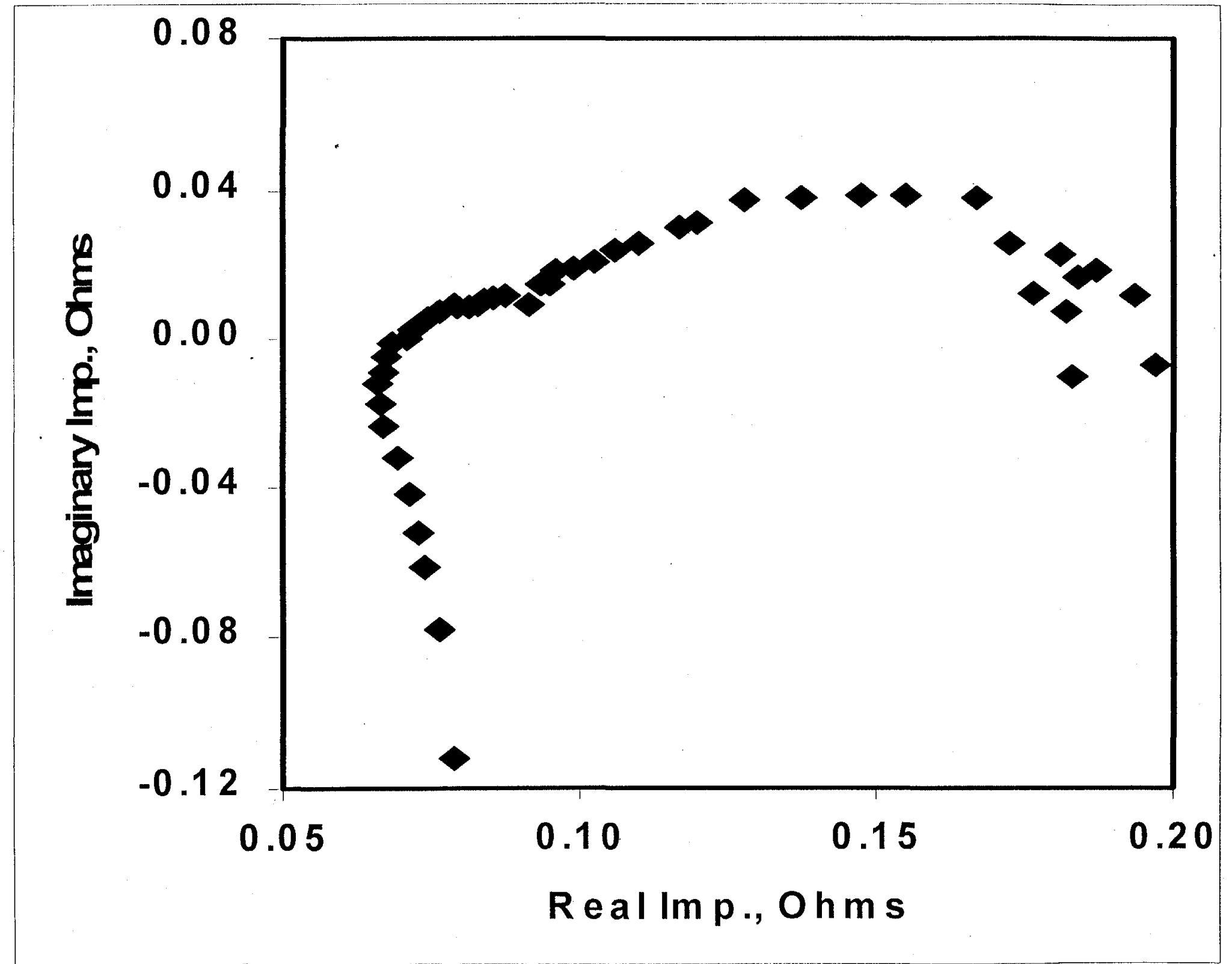




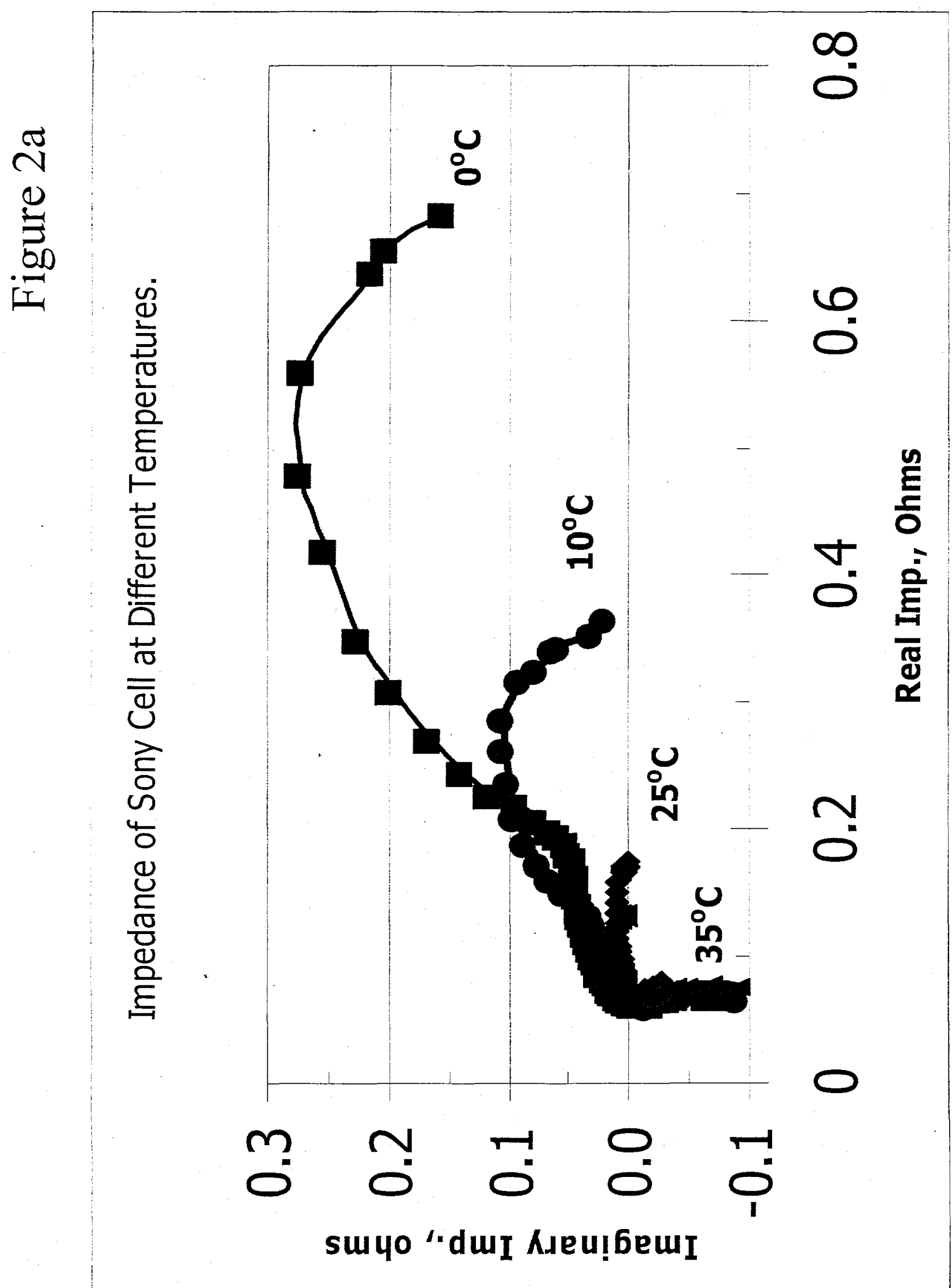




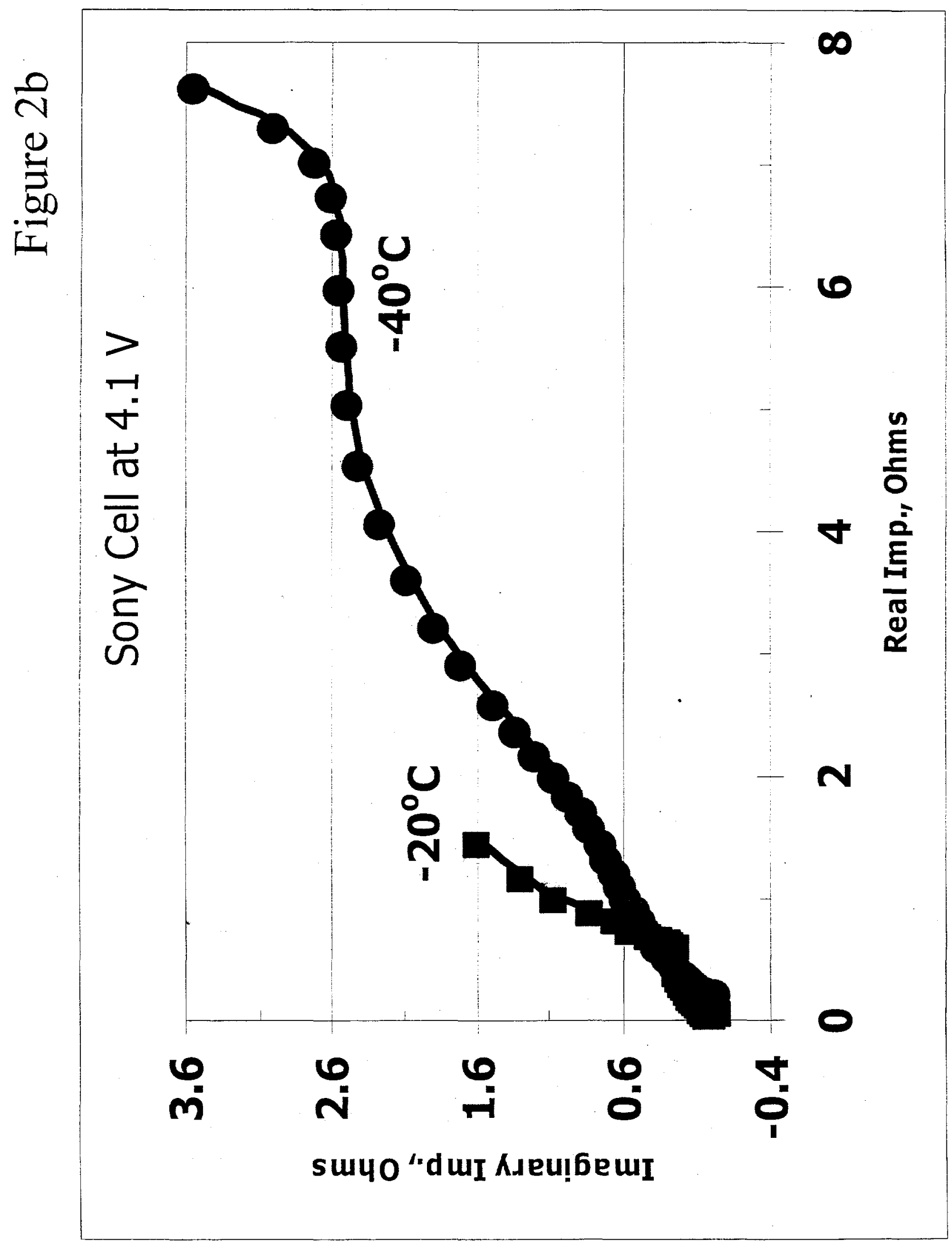




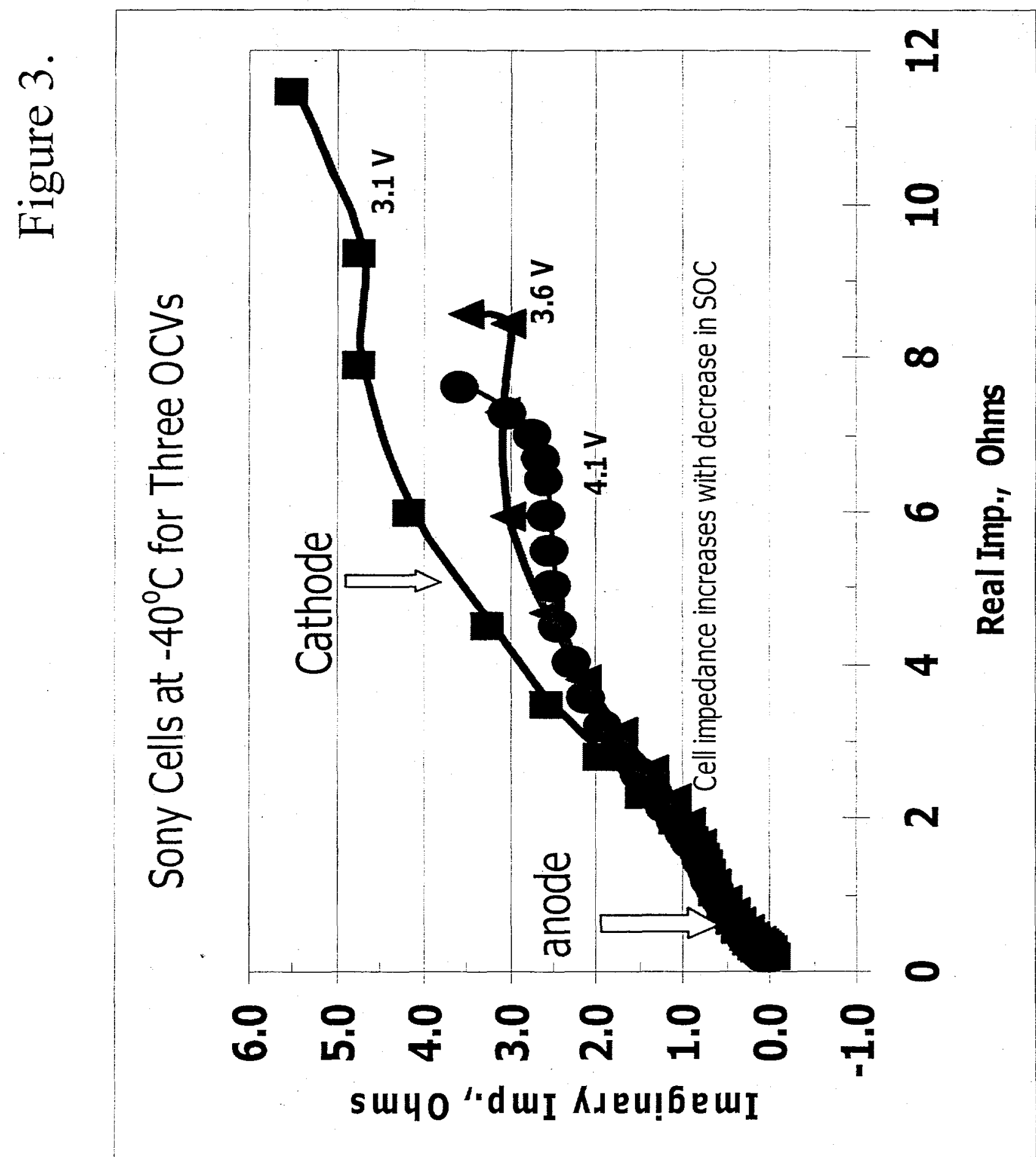


Figure 4

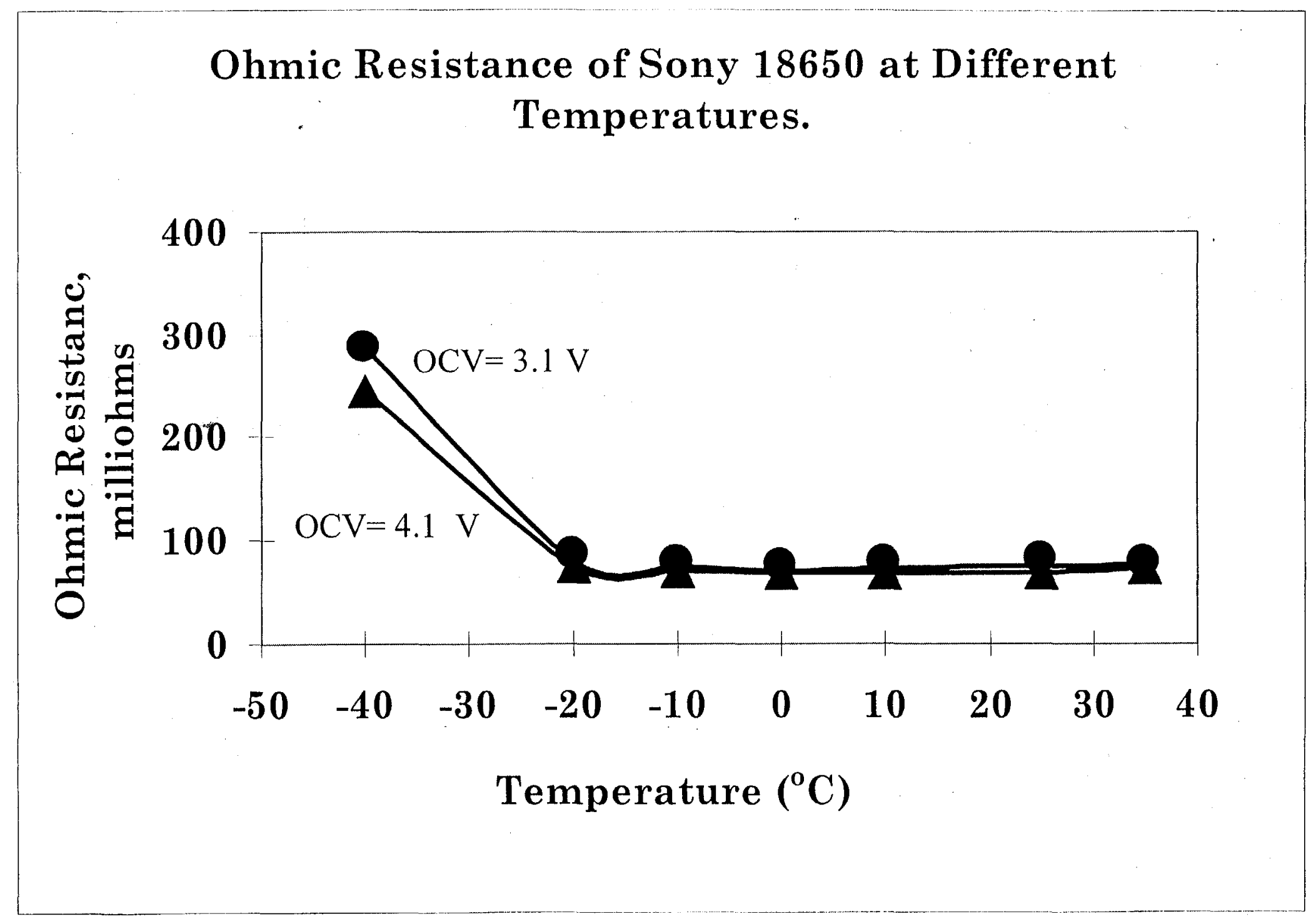


Figure 5

Sony Cell: Impedances of the anode, Cathode and the full cell at $0 \mathrm{C}$.

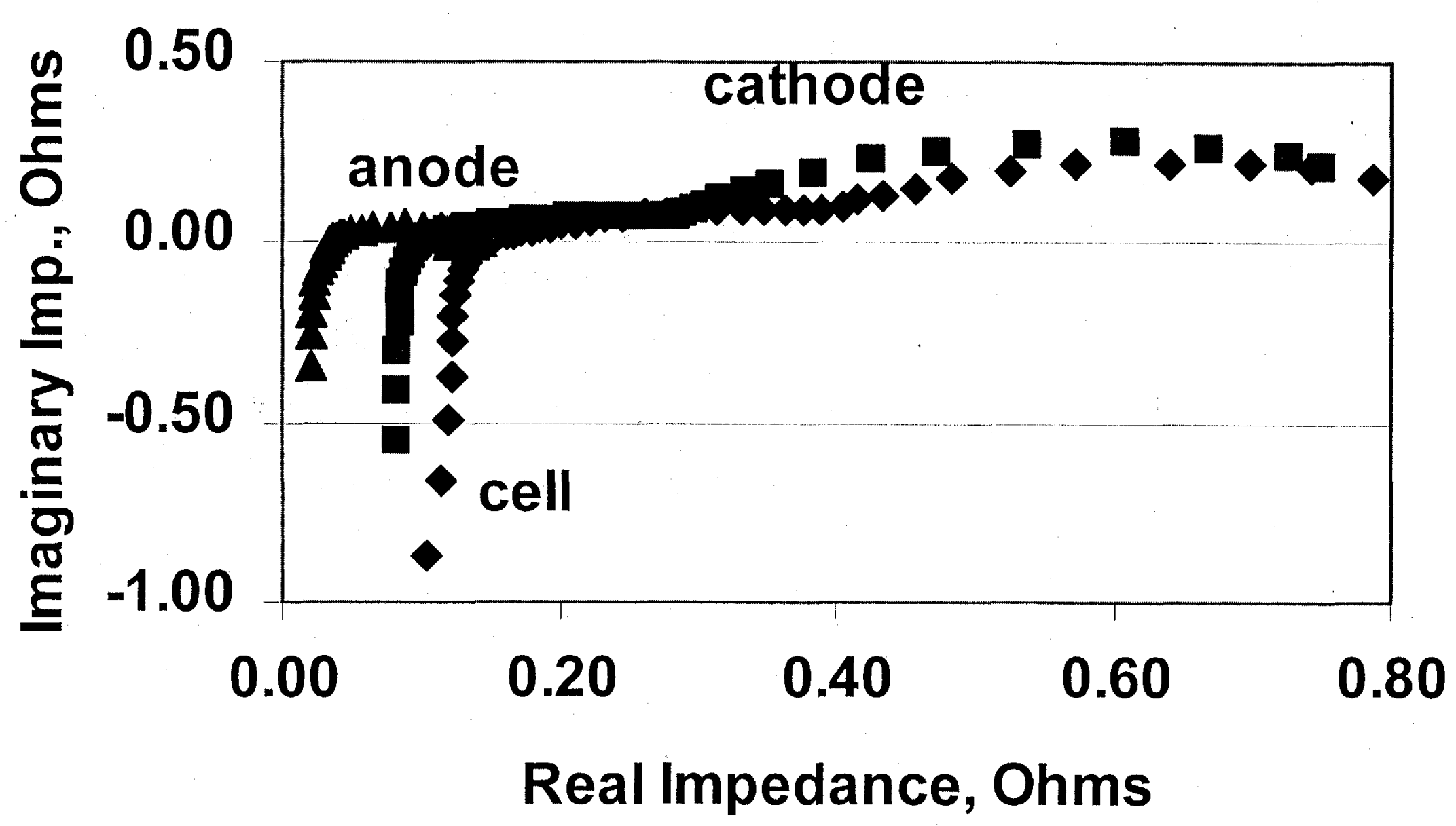


Sony Cell: Plots of Full Cell, anode and Cathode Impedances at $-20^{\circ} \mathrm{C}$

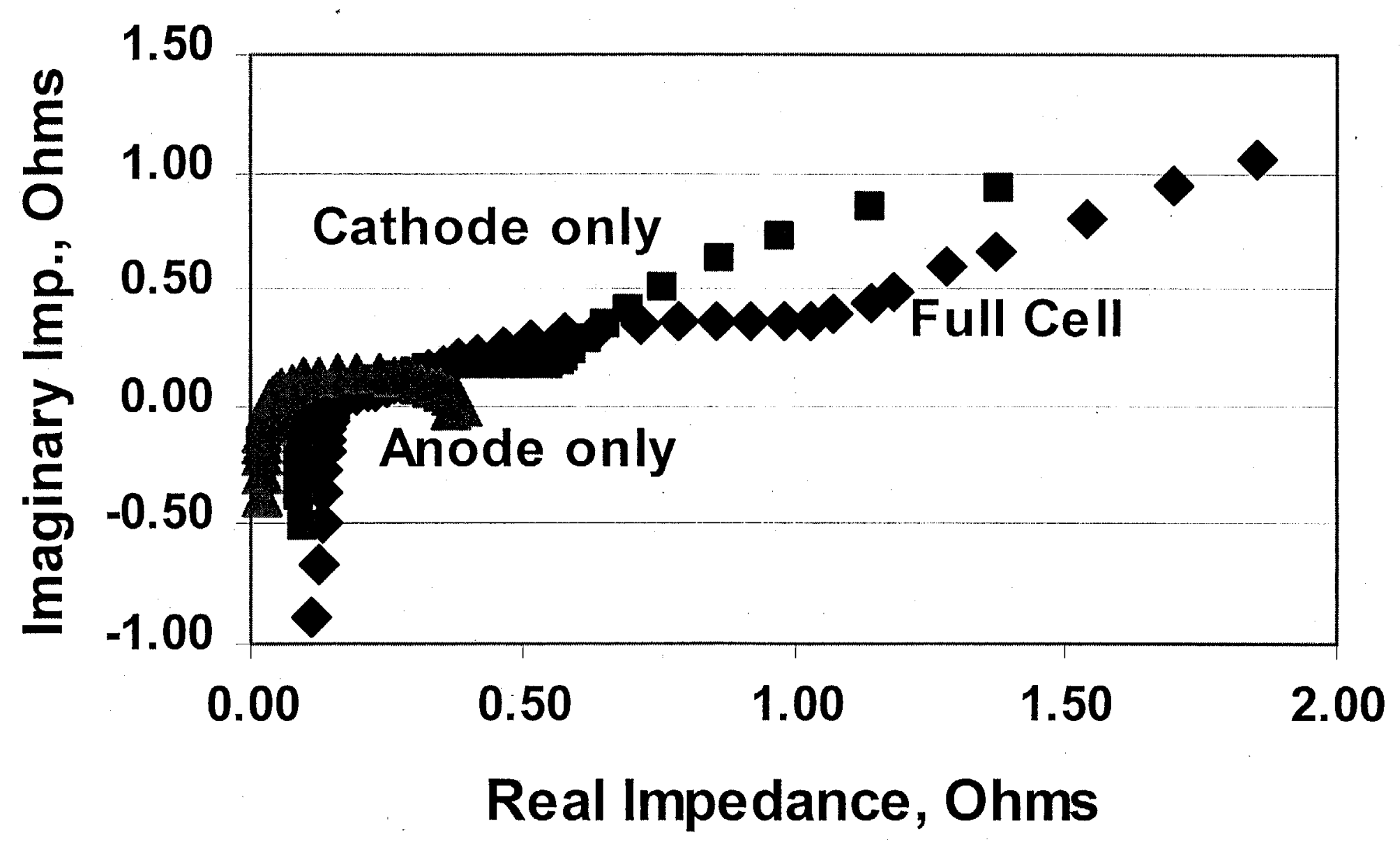




\section{Figure 7.}

Sony Cell: Impedances of full cell and the sum of anode and cathode at $0^{\circ} \mathrm{C}$

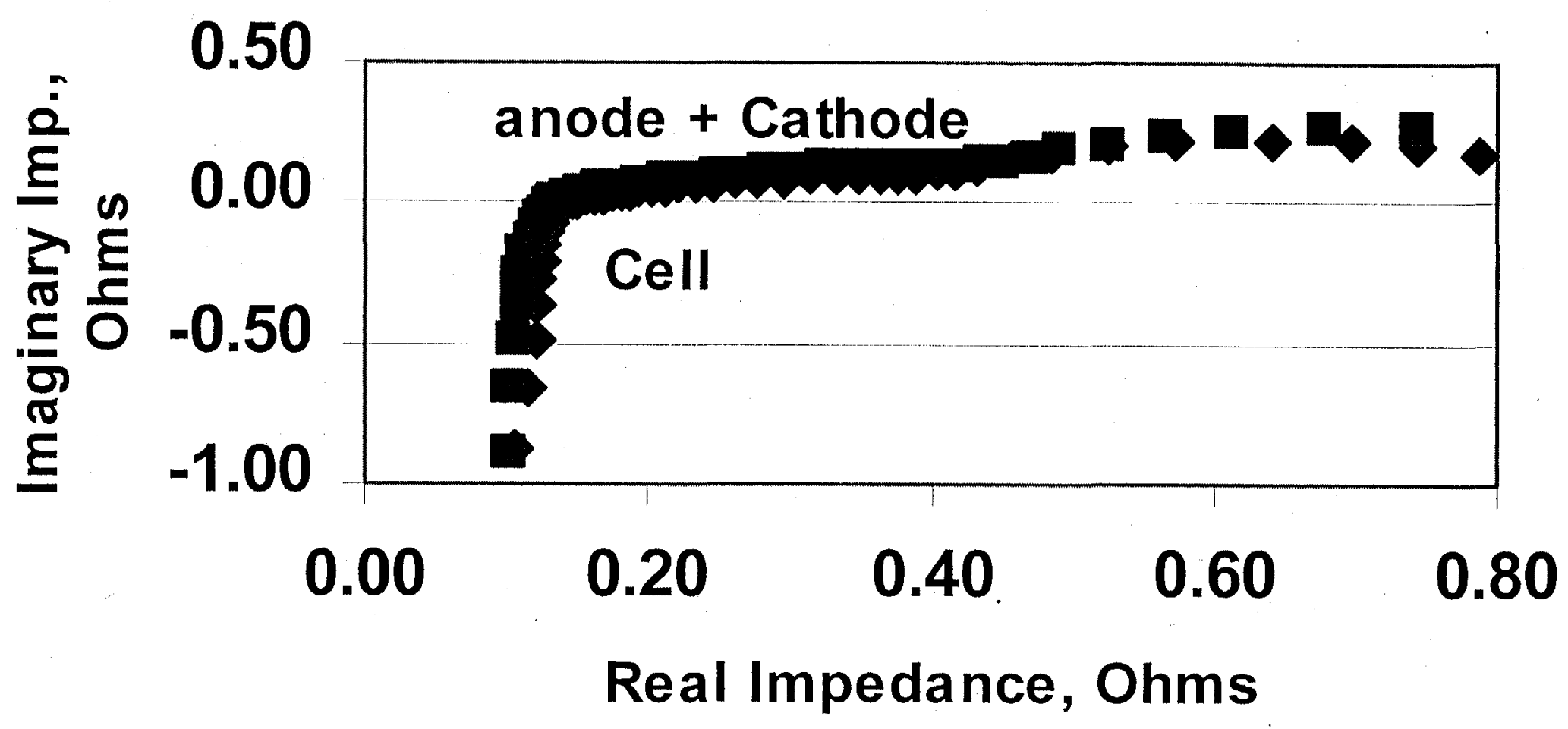



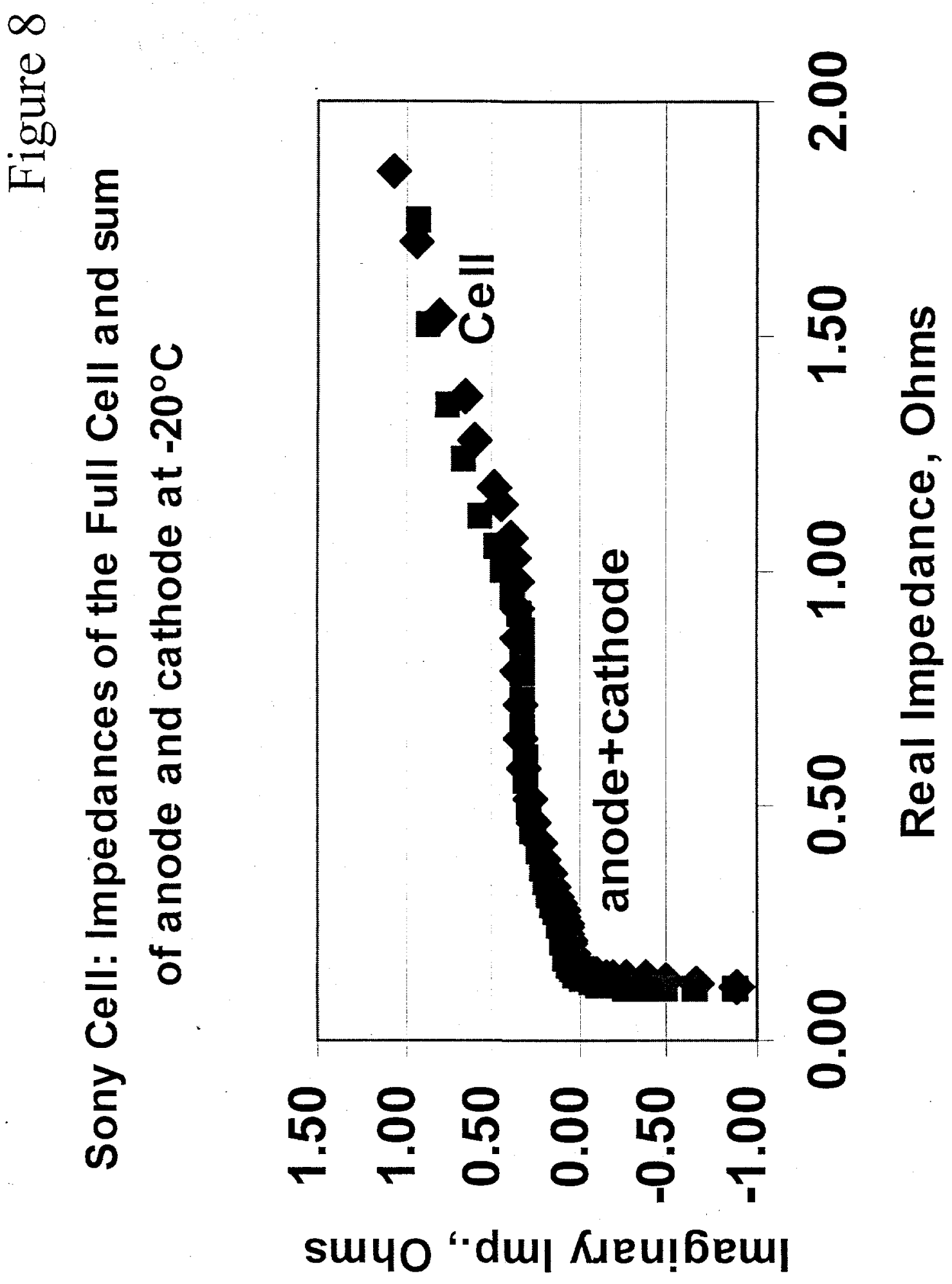